\title{
Prospek Penggunaan Isolat FMA Lokal di Lahan Pasang Surut Untuk Meningkatkan Produktivitas Kedelai
}

\author{
Ridwan Muis* \\ Jurusan Agroteknologi Fakultas Pertanian Universitas Jambi, Kampus Mendalo Jambi \\ *Correspondence email: ridwanmuis@ymail.com
}

\begin{abstract}
Abstrak. Lahan pasang surut memiliki masalah fisiko kimia lahan untuk pengembangan tanaman pangan yang kompleks meliputi genangan air dan kondisi fisik lahan, kemasaman tanah dan asam organik pada lahan gambut tinggi, mengandung zat beracun dan intrusi air garam, kesuburan alami tanah rendah dan keragaman kondisi lahan. Penggunaan pupuk an organik yang terus menerus selain membutuhkan biaya tinggi, juga berpeluang merusak keseimbangan lingkungan. Penggunaan isolat FMA lokal untuk efisiensi penggunaan pupuk $\mathrm{P}$ dan meningkatkan produktivitas kedelai menarik untuk dipertimbangkan, karena merupakan aktivitas yang ramah lingkungan..
\end{abstract}

Kata Kunci: Isolat FMA lokal; lahan pasang surut; produktivitas kedelai.

Abstract. Tidal field has physical and chemical problems of land for the development of complex food crops including waterlogging and land physical conditions, soil acidity and organic acids on high peatlands, containing toxic substances and salt water intrusion, low natural soil fertility and diversity of land conditions. The continuous use of inorganic fertilizers apart from requiring high costs, also has the opportunity to destroy the balance of the environment. The use of local AMF isolates for efficient use of $P$ fertilizers and increasing soybean productivity is interesting to consider, because it is an environmentally friendly activity

Keywords: local AMF isolates; tidal field; soybean productivity

\section{PENDAHULUAN}

Upaya peningkatan produksi dan produktivitas kedelai dihadapkan pada keterbatasan lahan, akibat pesatnya alih fungsi lahan. Oleh karena itu, pengembangan kedelai diarahkan pada lahan sub marjinal yaitu lahan pasang surut.

Untuk mengembangkan kedelai pada lahan yang mempunyai karakter khusus seperti lahan pasang surut, diperlukan varietas yang mampu beradaptasi pada kondisi tertentu dan tindakan budidaya yang sesuai. Beberapa varietas telah dicoba adaptasikan pada lahan pasang surut seperti Tanggamus, Wilis, Pangrango, Panderman, Lawit, Manyapa dan lain-lain, namun untuk memperoleh varietas yang unggul pada lokasi pasang surut tertentu, masih perlu uji coba lanjutan.

Penemuan varietas yang mampu beradaptasi dengan kondisi lahan surut di lokasi tertentu, harus diikuti oleh tindak budidaya yang mampu meningkatkan produktivitas, sekaligus mampu menekan pengaruh lapisan pirit. Lapisan pirit akan berpengaruh terhadap ketersediaan $\mathrm{P}$ tanah.

Kontradiktivitas penyediaan $\mathrm{P}$ melalui pemupukan khususnya pupuk an organik, selalu hangat diperbincangkan. Di satu pihak, pupuk $\mathrm{P}$ sangat diperlukan untuk memenuhi kebutuhan hara tanaman khususnya kedelai, namun di lain pihak, bila pemupukan dilakukan secara intensif dan dalam jumlah yang besar, maka berpeluang mencemari lingkungan. Oleh karena itu diperlukan upaya untuk memenuhi kebutuhan hara tanaman khususnya $\mathrm{P}$ terhadap kedelai, tetapi dengan sedikit sekali pengaruhnya terhadap penurunan kualitas lingkungan. Hal ini dapat dilakukan melalui penggunaan fungi mikoriza arbuskula yang mampu bersimbiosis dengan kedelai. Fungi mikoriza arbuskula mampu membantu tanaman inangnya menyerap $\mathrm{P}$ yang bersifat immobil di dalam tanah.

Fungi mikoriza arbuskula memiliki miselium yang menjulur sampai ke luar akar untuk menyerap hara bagi tanaman. Fungi mikoriza arbuskula menghasilkan asam organik dan enzim phosphatase yang mampu meningkatkan $\mathrm{P}$ terlarut, selanjutnya $\mathrm{P}$ terlarut disalurkan kepada tanaman inang melalui hifa eksternal FMA. Mekanisme inilah yang mengakibatkan Fungi Mikoriza Arbuskula dapat meningkatkan pengambilan fosfat dari sumbernya.

\section{METODE}

Adapun metode penelitian kajian pustaka atau studi kepustakaan yaitu berisi teori teori yang relevan dengan masalah - masalah penelitian. Adapun masalah pada penelitian ini adalah untuk mengetahui "Prospek Penggunaan Isolat FMA Lokal di Lahan Pasang Surut Untuk Meningkatkan Produktivitas Kedelai”. Pada bagian ini dilakukan pengkajian mengenai konsep dan teori yang digunakan berdasarkan literatur yang tersedia, terutama dari artikel-artikel yang dipublikasikan dalam berbagai jurnal ilmiah. Kajian pustaka berfungsi untuk membangun konsep atau teori yang menjadi dasar studi dalam penelitian. (Sujarweni, 2014) 


\section{HASIL DAN PEMBAHASAN Kedelai}

Produksi kedelai di Indonesia pada Tahun 2018 mencapai 982.5980 ton dari luas panen 680.373 ha dengan roduktivitas 1,44 ton ha melalui program Upaya Khusus Padi jagung kedelai (Pajale) yang dimulai sejak Tahun 2015 (Kementerian Pertanian, 2018). Meskipun mengalami peningkatan produksi sebesar 443.870 ton jika dibandingkan pada Tahun 2017 yang hanya mencapai 538.728 ton dari luas panen 355.799 ha, namun menunjukkan penurunan produktivitas sebesar 0,07 ton ha- ${ }^{1}$.

Sejalan dengan pesatnya alih fungsi lahan, maka perhatian diarahkan pada pemanfaatan lahan-lahan potensial khususnya untuk budidaya kedelai. Lahan dimaksud adalah lahan rawa pasang surut dan rawa lebak. Menurut Alihamsyah (2003), diperkirakan terdapat 5.6 - 9.9 juta hektar ahan rawa pasang surut dan rawa lebak di Indonesia. Dari jumlah tersebut, 0.9 juta haberada di Sumatera. Budidaya kedelai pada lahan ini cukup memadai, namun cara budidaya yang dilakukan berbeda daripada di lahan sawah irigasi dan lahan kering.

\section{Lahan Pasang Surut}

Lahan pasang surut adalah lahan yang rejim airnya dipengaruhi oleh pasang surutnya air laut atau sungai. Berdasarkan sifat kimia air pasangnya, lahan pasang surut dibagi menjadi dua zona yaitu zona air pasang surut salin dan pasang surut air tawar. Lahan pasang surut berdasarkan hidrotopografi dibedakan menjadi empat tipe yang membutuhkan manajemen yang berbeda. Tipe A merupakan daerah rawa yang selalu terluapai air pasang besar maupun pasang kecil. Tipe B adalah lahan yang hanya terluapi oleh pasang besar. Tipe $\mathrm{C}$ merupakan lahan yang tidak terluapi air pasang, baik pasang besar maupun pasang kecil tetapi kedalaman air tanah kurang dari $50 \mathrm{~cm}$ dari permukaan tanah. Tipe $\mathrm{D}$ adalah lahan tidak terluapi air pasang baik pasang besar maupun pasang kecil tetapi kedalaman air tanah lebih dari $50 \mathrm{~cm}$ dari permukaan tanah.

Lahan pasang surut berdasarkan tipologi lahannya, dibagi menurut macam dan tingkat masalah fisiko kimia tanahnya, yaitu 1) lahan potensial, kedalaman lapiran pirit $>50 \mathrm{~cm}$ dari permukaan tanah, 2) lahan sulfat masam (sulfat masam potensial dan sulfat masam aktual), bila kedalaman lapisan pirit $\left(\mathrm{FeS}_{2}>2 \%\right)<50 \mathrm{~cm}$ dari permukaan tanah, 3) lahan gambut, mengandung lapisan sisa-sisa tanaman yang sudah lapuk secara alami, 4) lahan salin, dipengaruhi oleh intrusi air laut selama lebih dari 3 bulan dalam setahunnya. Berdasarkan tipologinya, lahan gambut merupakan tipe lahan pasang surut yang terluas (10.9 juta ha), kemudian diikuti lahan sulfat masam (6.7 juta ha), lahan potensial (2.1 juta ha) dan lahan salin (0.4 juta ha). Menurut Alihamsyah (2003) Ketersediaan lahan pasang surut di Indonesia berdasakan tipologi lahan adalah: lahan gambut kurang lebih 10890000 ha $(54.26 \%)$, lahan sulfat masam 6670000 ha $(33.24 \%)$, lahan potensial 2 070000 ha $(10.31 \%)$ dan salin 440000 ha $(2.19 \%)$. Selanjutnya dijelaskan bahwa 1) lahan gambut, mengandung lapisan sisa-sisa tanaman yang sudah lapuk secara alami, 2) lahan sulfat masam (sulfat masam potensial dan sulfat masam aktual), bila kedalaman lapisan pirit $\left(\mathrm{FeS}_{2}>2 \%\right)<50 \mathrm{~cm}$ dari permukaan tanah, 3) lahan potensial, kedalaman lapiran pirit $>50 \mathrm{~cm}$ dari permukaan tanah, 4) lahan salin, dipengaruhi oleh intrusi air laut selama lebih dari 3 bulan dalam setahunnya.

Budidaya pertanian khususnya kedelai, pada lahan sulfat masam, dihadapkan pada kendala yang lebih berat. Lahan sulfat masam mempunyai lapisan pirit yang pada kondisi teroksidasi mengakibatkan $\mathrm{pH}$ tanah yang masam sampai sangat masam, kandungan dan ketersediaan hara yang rendah serta mempunyai kandungan unsur meracun $\mathrm{Al}$ dan $\mathrm{Fe}$ yang tinggi.Bla lahan sulfat masam tergenang (reduktif), maka kadar fero akan semakin banyak yang daat mengakibatkan keracunan besi pada kedelai. Secara umum, kendala yang dihadapi budidaya kedelai pada lahan pasang surut adalah keragaman kondisi lahan tinggi, kesuburan tanah rendah, kemasaman tanah tinggi, asam organik pada lahan gambut tinggi,genangan air dan kondisi fisik lahan yang kurang baik, serta intrusi air garam.

\section{Fungi Mikoriza Arbuskula}

Fungi Mikoriza Aebuskula adalah jenis fungi yang bersifat obligat fakultatif yaitu fungi yang untuk kelangsungan hidupnya memerlukan tanaman inang dan tidak dapat ditumbuhkan pada media buatan di laboratorium. Oleh karena itu FMA hidup berkoloni pada beberapa jenis tanaman pertanian dan kehutanan. FMA melindungi perakaran dari serangan patogen dan memperbaiki ketersediaan hara fosfor sehingga mampu meningkatkan pertumbuhan tanaman..

Asosiasi mikoriza fakultatif merupakan asosiasi setimbang, tanaman akan mendapat keuntungan tergantung pada kondisi kesuburan tanahnya. Hasilhasil percobaan menunjukkan tanaman-tanaman bermikoriza fakultatif akan mendapatkan keuntungan dari Fungi FMA hanya jika kadar fosfor dalam tanah cukup rendah dan tanaman-tanaman demikian dicirikan dengan akar yang relatif lebih panjang, kurus dan bercabang banyak dengan rambut-rambut akar yang panjang jika dibandingkan dengan species-species tanaman bermikoriza obligat.

Sebagai bagian dari makhluk hidup, maka perkecambahan spora FMA sangat dipengaruhi oleh faktor lingkungan. Kondisi lingkungan yang dibutuhkan FMA sama dengan yang dibutuhkan untuk perkecambahan biji dan pertumbuhan akar tanaman. FMA memiliki ketahanan yang cukup baik pada rentang faktor lingkungan fisik yang cukup lebar. Akibatnya FMA dapat berkembang pada lahan yang tergenang seperti sawah. FMA masih memperlihatkan 
eksistensinya pada lingkungan yang tercemar limbah berbahaya dan ada lingkungan yang sangat miskin hara. .

Bagi tanaman inang, FMA memberikan kontribusi yang sangat besar karena mampu memperbesar areal serapan bulu-bulu akar melalui pembentukan miselium di sekeliling akar. Kondisi ini membuat tanaman yang bermikoriza mamu memperbesar volume jelajah akar. Dengan demikian tanaman bermikoriza memiliki kemampuan menyerap air dan unsurhara yang lebih baik dibandingkan dengan tanaman yang tidak bermikoriza. Hubungan antara FMA dengan tanaman inangnya merupakan hubungan yang saling menguntungkan (simbiosis mutualistis), FMA akan memanfaatkan sebagian asimilat yang berada di akar tanaman untuk kebutuhannya, sedangkan tanaman akan memperoleh hara $\mathrm{P}$, air dan hara lain yang ikut dalam aliran masa, sebagai aktivitas FMA.

Asosisasi FMA hanya akan meningkatkan produktivitas tanaman jika keuntungan yang dihasilkan oleh membaiknya hara mineral dan faktor-faktor lain melampaui biaya produksi untuk membangun asosiasi FMA. Dalam kondisi tertentu dapat terbentuk asosiasi oportunistik antara FMA dengan tanaman bukan inang atau antara tanaman dengan FMA yang tidak berasosiasi. Asosiasi demikian dapat disebut sebagai antagonisme karena hal tersebut dapat merusak salah satu jasad hidupnya. Antagonisme tanaman dengan mikoriza tipe lainnya disebabkan oleh terbatasnya ketersediaan hara atau penghambatan aktivitas FMA oleh alelopati.

Habitat yang baik untuk pertumbuhan FMA adalah rhizosfer, karena di daerah rhizosfer terdapat eksudat akar. Perbandingan jumlah FMA yang berada di daerah rhizosfer dengan yang berada di tanah sering dikodifikasi dengan R/S dan nilainya berkisar 5 samai 20. Nilai R/S ini akan semakin kecil dengan semakin suburnya tanah. Hubungan simbiosis antara FMA dengan akar tanaman dimulai dengan perkecambahan spora FMA kemudian kecambah ini menginfeksi akar tanaman. FMA akan tumbuh dan berkembang biak di dalam jaringan akar tanaman membentuk hifa yang panjang dan bercabang. Hifa FMA yang memiliki jangkauan yang luas akan berperan sebagai akar untuk menyerap air dan hara dari dalam tanah.

Beberapa faktor lain yang mempengaruhi jumlah spora di dalam tanah adalah: umur tanaman, musim dalam setahun serta masa sporulasi FMA. Spora akan terbentuk akibat stres lingkungan dan ketidakseimbangan nutrisi. Namun pertumbuhan spora akan dihambat oleh aerasi tanah yang buruk, tanah yang kedap air dan sangat peka terhadap erosi.

Idang serapan air dan hara tanaman akan diperluas oleh jaringan hifa fungi mikoriza arbuskula. Hipa fungi mikoriza arbuskula bisa menyerap air pada kondisi kadar air tanah yang sangat rendah, karena hifa fungi mikoriza arbuskula bisa menyusup ke pori-pori tanah yang paling kecil (mikro), akibat ukuran hifa yang lebih halus dari bulu-bulu akar. Serapan hara N, K dan $S$ juga meningkat, karena tanaman yang bersimbiosis dengan fungi mikoriza arbuskula membawa unsur hara yang mudah larut dalam aliran masa. Kemampuan hifa fungi mikoriza arbuskula mengeluarkan enzim phosphatase, akan melepaskan $\mathrm{P}$ dari ikatan-ikatan spesifik, sehingga tersedia bagi tanaman. Kondisi ini semakin meningkatkan serapan P tanaman.

Pada awalnya FMA tumbuh di antara sel-sel korteks tapi kemudian menembus dinding sel dan tumbuh di dalam lumen sel. Dinding sel dan membransel inang pasti akan ditembus oleh hifa FMA. Jika FMA tumbuh, membran sel kemudian menyelubungi Fungi dan membentuk ruangan baru yang berisikan bahan dengan kompleksitas molekuler yang sangat tinggi. Ruangan tersebut mencegah terjadinya kontak langsung antara sitoplasma tanaman dan sitoplasma Fungi sehingga memungkinkan terjadinya perpindahan hara yang efisien antara tanaman dan FMA. Arbuskula pada umumnya berumur pendek dan seringkali sulit diamati sekalipun dengan bantuan mikroskop.

Dari sudut pandang ekosistem, aliran karbon menuju ke tanah yang dimediasi oleh mikoriza melahirkan banyak fungsi. Hifa eksternal matrikal menghasilkan enzim hidrolitik, misalnya fosfatase yang berperan penting dalam mineralisasi bahan organik dan ketersediaan hara. Selain itu hifa ekstra matrikal juga mengikat partikel-partikel tanah menjadi satu sehingga memperbaiki agregasi tanah. Karbon yang dialirkan ke rizosfir akan digunakan sebagai substrat bagi jasad renik rizosfir lainnya. Dengan demikian FMA yang mengkolonisasi akar pada akhirnya akan berinteraksi dengan keseluruhan penghuni akar baik yang patogen maupun non patogen yang sama-sama memparasit jaringan akar yang sama dan mendapatkan karbon dari tanaman inang yang sama. Interaksi tersebut dapat bersifat positif, netral ataupun negatif bagi mikoriza mapun peubah-peubah lain rizosfir.

Jika fosfor tersedia dalam jumlah yang tinggi, walaupun hal ini bukan hal yang umum terjadi pada tanah pertanian, maka FMA tidak akan bertindak sebagai agen simbiosis mutualistik. Persentase derajat infeksi akar juga dipengaruhi oleh jumlah spora. Kondisi ini diperoleh oleh Ferry dan Towaha (2013) dalam penelitiannya bahwa pemberian fungi mikoriza arbuskula dengan kepadatan spora yang tinggi dapat meningkatkan pertumbuhan tanaman dibandingkan dengan kepadatan spora rendah pada tanaman selasih. Kepadatan spora berkorelasi positif dengan peningkatan kolonisasi akar, penyerapan unsur hara menjadi lebih baik sehingga akan memacu pertumbuhan tanaman.

Persentase derajat infeksi mikoriza pada akar kedelai akan dipengaruhi oleh pemupukan $\mathrm{P}$ dengan dosis tinggi. Berdasarkan penelitiannya, Widiastuti, Guhardja dan Soekarno (2002) mendapatkan bahwa dengan pemberian $\mathrm{P}$ dosis rendah yaitu $25 \%$ dari rekomendasi menghasilkan kondisi optimal simbiosis fungi mikoriza arbuskula pada kelapa sawit. 
Penelitiannya juga mendapatkan bahwa pemupukan $\mathrm{P}$ dengan dosis tinggi akan menghambat perkecambahan spora dan pertumbuhan hifa. Penelitian Susanti, Faizah dan Wibowo (2018) juga memperoleh kenyataan bahwa dibandingkan dengan kandungan $\mathrm{P}$ cukup, maka kandungan $\mathrm{P}$ rendah akan memberikan pengaruh inokulasi mikoriza yang lebih baik.

Melalui pengelolaan mikoriza yang tepat juga memungkinkan untuk merawat kualitas dan keberlanjutan tanah, sekaligus melindungi lingkungan dalam jangka panjang serta menurunkan biaya produksi. FMA mengkolonisasi tanaman inang untuk mendapatkan karbon hasil fotosintesis tanaman dan sebagai imbalannya FMA membantu tanaman mendapatkan hara dari dalam tanah, yaitu dengan menangkap dan mengangkut hara mineral, khususnya fosfor dari dalam tanah ke dalam jaringan tanaman. Fosfat dalam tanah pada umumnya terdapat dalam berbagai bentuk namun secara umum dapat dipilahkan menjadi dua yaitu fosfat organik dan fosfat an organik.

\section{Prospek}

Kegiatan pertanian yang sangat intensif dan menggunakan pupuk an organik secara terus menerus dan dalam jumlah yang besar akan menyebabkan kerusakan fisika, kimia dan biologi tanah serta pencemaran lingkungan. Kondisi ini mengakibatkan keprihatinan dan kepedulian terhadap lingkungan semakin bertambah, sehingga perlu mengupayakan solusi teknologi alternatif untuk meminimalisir kerusakan tersebut, tetapi tetap mampu meningkatkan produktivitas dan kualitas tanaman. Di antara solusi teknologi alternatif yang mungkin dilakukan adalah penggunaan fungi mikoriza arbuskula.

Fungi mikoriza arbuskula membentuk hifa yang tumbuh pada akar tanaman dan berfungsi sebagai perluasan dari permukaan akar. Hifa ini dapat menyebar ke daerah-daerah kahat $\mathrm{P}$ dan mengangkutnya ke dalam akar dan dapat dimanfaatkan tanaman untuk pertumbuhan. Oleh karena itu, peran utama FMA dalam mengatasi kekahatan $\mathrm{P}$ adalah kemampuannya untuk mentranslokasikan $\mathrm{P}$ tanah ke dalam tanaman. Akibatnya aplikasi FMA dilakukan untuk mengurangi ketergantungan pupuk $\mathrm{P}$ dan meningkatkan ketersediaan fosfat. Di samping itu, penggunaan FMA diharapkan mampu meningkatkan ketahanan tanaman terhadap patogen akar.

Simbiosis FMA dengan tanaman kedelai selain meningkatkan penyerapan $\mathrm{P}$, air dan hara yang mudah larut dan terbawa dalam aliran masa, juga mampu meningkatkan ketahanan kedelai terhadap kekeringan. Peningkatan ketahanan terhadap kekeringan ini sangat dimungkinkan karena meningkatnya jumlah dan bobot kering akar.

Agar terjadi kompatibilitas dalam sebuah simbiosis, maka kedua simbion harus menggunakan fungsi simbiosis secara penuh, tidak terkecuali pada simbiosis FMA dengan kedelai sebagai tanaman inang. FMA menembus akar tanaman inang dan membentuk arbuskula tempat bahan-bahan (fosfat dan karbohidrat) dipertukarkan dan mempengaruhi perkembangbiakan FMA. Kedelai dapat tumbuh dan berkembang secara sempurna karena mendapat pasokan air dan hara dari FMA.

FMA menarik untuk diperhatikan karena memiliki kemampuan berasosiasi membentuk simbiosis mutualistik dengan hampir $80 \%$ spesies tanaman. Kompatibilitas FMA dengan tanaman inang sangat bervariasi bergantung pada spesies FMA, spesies tanaman inang dan kondisi lingkungannya. Simbiosisi FMA dengan tanaman inang dimulai dari infeksi akar oleh FMA. FMA berasaaal dari propagul (spora dari residu akar) atau dari akar yang berdekatan dengan tanaman yang sama atau berbeda spesies tanaman. Kemampuan menginfeksi akar tanaman inang karena adanya sinyal berupa eksudat flavonoid dari akar. Dinata (2019) dalam penelitiannya mendapatkan bahwa penggunaan FMA meningkatkan produksi kedelai sebesar 29,2 - 35,8\%. Hapsoh (2003) memperoleh kenyataan dalam penelitiannya bahwa aplikasi FMA terhadap kedelai mampu meningkatkan hasil biji kering kedelai pada genotipe peka kekeringan sebesar 76,42\% dan genotipe toleran kekeringan sebesar 36,68\%.

Infeksi akar oleh mikoriza dimulai dari propagul (spora dari residu akar) atau dari akar yang berdekatan dengan tanaman yang sama atau berbeda spesies tanaman. Propagul mampu menginfeksi akar tanaman inang karena adanya sinyal berupa eksudat flavonoid dari akar. FMA banyak mendapat perhatian karena kemampuannya berasosiasi membentuk simbiosis mutualistik dengan hampir $80 \%$ spesies tanaman. Menurut beberapa peneliti, kompatibilitas FMA dengan tanaman inang sangat bervariasi bergantung pada spesies FMA, spesies tanaman inang dan kondisi lingkungannya. Penelitian Hapsoh (2008) FMA meningkatkan hasil biji kering kedelai pada genotipe peka kekeringan sebesar $76,42 \%$ dan genotipe toleran kekeringan sebesar 36,68\%, sedangkan Dinata (2019) dalam penelitiannya mendapatkan bahwa penggunaan FMA meningkatkan produksi kedelai sebesar 29,2 $35,8 \%$.

\section{Kesimpulan}

1. Lahan pasang surut merupakan lahan sub marjinal yang potensial untuk perluasan areal tanaman kedelai dengan memperhatikan faktor pembatas fisiko kimia yang dimilikinya.

2. Penggunaan isolat FMA lokal merupakan alternatif dalam mengefisienkan penggunaan pupuk $\mathrm{P}$ dan meningkatkan produktivitas kedelai.

\section{Daftar Pustaka}

Alihamsyah T. 2003. Hasil penelitian pertanian pada lahan pasang surut. Prosiding Seminar Nasional 
Hasil-hasil Penelitian dan Pengkajian Teknologi Spesifik Lokasi Jambi, 18-19 Desember 2003. Jambi (ID): BPTP Jambi dan Bappeda Jambi

Dinata N. 2019. Respon pertumbuhan dan produksi beberapa varietas tanaman kedelai (Glycine max L.) tehadap pemberian Fungi Mikoriza Arbuskular (FMA) pada tanah ultisol. Skripsi. Medan: Universitas Muhammadiyah Sumatera Utara

Ferry Y, J. Towaha, RRKD. Sasmita. 2013. Pemanfaatan kompos tanaman air sebagai pembawa inokulan mikoriza pada budidaya lada perdu di lahan bekas tambang timah. Jurnal Littri 19 (1), 19-22

Hapsoh, H. 2008. Pemanfaatan fungi mikoriza arbuskular pada budidaya kedelai di lahan kering. Pidato Pengukuhan Jabatan Guru Besar Tetap dalam Bidang Ilmu Budidaya Pertanian pada Fakultas Pertanian,diucapkan di hadapan Rapat Terbuka Universitas Sumatera Utara Gelanggang Mahasiswa, Kampus USU, 14 Juni 2008. Universitas Sumatera Utara, Medan. 31p.

Kementerian Pertanian. 2018. Statistik Pertanian 2018. Pusat Data dan Sistem Informasi Pertanian Kementerian Pertanian Republik Indonesia. Jakarta.

Susanti A, M. Faizah dan R. Wibowo. 2018. Uji infektivitas mikoriza indigenous terhadap tanaman kedelai terinfeksi Phakosora pachyrhizi Syd. Seminar Nasional Multidisiplin 2018. UNWAHA. Jombang.

V.Wiratna Sujarweni, 2014. Metodeologi Penelitian. Yogyakarta: Pustaka Baru Perss

Widiastuti H, E. Guhardja, N. Soekarno, LK. Darusman, GH. Goenadi dan S. Smith. 2002. Optimasi simbiosis cendawan mikororiza arbuskula Auclospora tuberculata dan Gigaspora margarita pada bibit kelapa sawit di tanah masam. Menara Perkebunan 70 (2), 50-57 